\title{
Stepping stones to market integration The role of economic and technological development zones
}

\section{Wei Zhang}

China's National People's Congress passed the Enterprise Income Tax Law of the People's Republic of China in March 2007. This new law unified enterprise income tax rates applied to domestic and foreign-invested firms. The passage of the new law is part of the Chinese government's efforts to provide a level playing field for business competition between domestic and foreign-invested firms. This legislation is also a significant step towards China fulfilling its World Trade Organization (WTO) obligations. After a short transitional period, the changes in tax rates and taxing practice will end most of the privileges enjoyed by foreign-invested enterprises located in various special economic zones (SEZs) in China. This attracts broad attention to the role and the future of China's SEZs.

Setting up SEZs has been a popular policy tool for developing and industrialised countries to implement their trade, industry and regional policies. An SEZ is an area that has economic laws and management systems different from those in the rest of the country. The main goals of developing such a zone are to attract inward foreign direct investment (FDI), expand exports, increase the fiscal income of foreign exchange, spur local employment and promote development of technology. Special policy incentives provided to achieve such goals usually include provision of better infrastructure, preferential tax treatments, privileged trading terms and less bureaucratic administrative procedures.

SEZs have various forms. The World Export Processing Zones Association categorises different zones according to their various size, industry and performance specifics (WEPZA 2007). For example, there are some large SEZs 
in the world that cover or are integrated within an entire city, or even a whole region; there are also some relatively small export processing zones with an area less than 1,000 hectares. There are some industrial parks specialised in certain industries, and some high-tech parks attracting and supporting firms that possess or develop high or new technologies.

The various forms of SEZs have developed very rapidly in the past few decades. According to Crittle and Akinci (2004), the number of SEZs in the world increased from 80 to 3,000 from the late 1970 s to the early 2000 s; the number of countries that hosted SEZs increased from about 30 to more than 120. The value of export goods produced in such zones increased from US $\$ 6$ billion to US $\$ 600$ billion, and the number of people employed within the zones increased from one million to 50 million.

Since China started its economic reforms in 1978, it has become the country that holds the largest number of various forms of SEZs in the world. The first SEZ in China was approved in 1979. By the end of 2006, there were 1,568 SEZs across the country. The total planning area of SEZs was 9,949 square kilometres (State Commission of Development and Reform, Ministry of Land and Natural Resources, and Ministry of Construction 2006).

During the same period, the Chinese economy also witnessed the fastest growth, compared with its own history and compared with the rest of the world.

The phenomenal surge in the number of SEZs, coinciding with rapid economic growth, has invited broad attention from scholars and policymakers. The role of SEZs has always been highly contentious, globally and in China (Aggarwal 2006). Very often, creation of SEZs has been described as one of the most powerful engines driving China's economic growth. On the other hand, the pro-SEZ policies of the Chinese government have also drawn much criticism, especially because of their negative impacts, such as the misuse of arable land, distortion of the domestic market, expansion of regional disparities and unfair trade competition in the international market (Carttier 2001; Weil 1996; Gopalakrishnan 2007).

There are many different forms of SEZs in China. They can be divided into two main categories: 'Jingji Tequ' (special economic zones: in order to distinguish this specific form from the general term of SEZ, it is specified in this chapter as China's Special Economic Zones, hereafter CSEZs); and 'Kaifaqu' (Economic Development Zones, EDZs). Within the category of the EDZs, there are Jingji Jishu Kaifaqu (Economic and Technological Development Zones, ETDZs), Gaoxin Jishu Kaifaqu (High and New Technology Development Zones, HTDZs), Baoshuiqu (Free Tariff/Trade Zones, FTZs), Chukou Jiagongqu 
(Export Processing Zones, EPZs), Bianjing Jingji Hezuoqu (Bordered Economic Cooperative Zones, BECZs), and others.

This chapter attempts to explain the historical and special policy treatments of SEZs in China, to evaluate their role in promoting national economic reform and development and to analyse the challenges they are facing in the WTO era. While the paper presents the general development of various forms of SEZs, it will focus more on ETDZs - in particular, national-level ETDZs. This is due not only to the lack of research on ETDZs in China compared with the abundant research literature on CSEZs, but because ETDZs have hugely outnumbered SEZs and now spread to every province, municipality and autonomous region. This broad geographical coverage and resulting close relationships between ETDZs and their surrounding areas enables them to play a very effective role in introducing new management ideas, internationally recognised business practices and competitive technological innovations to the rest of the country.

Other forms of EDZs are either small pieces of land located within ETDZssuch as EPZs and HTDZs_or zones that enjoy similar preferential policies to those of ETDZs, although they are located in separate locations, such as TDZs and BECZs.

\section{Creation and development of ETDZs}

ETDZs were an extension of successful experiments with CSEZs. In July 1979, as part of a national reform plan, the central government decided to establish four CSEZs in southern Chan State: Shenzhen, Zhuhai and Shantou in Guangdong Province, and Huli (expanded to the whole island of Xiamen in 1984) in Fujian Province. ${ }^{1}$

With privileges such as a much higher degree of autonomy and a series of favourable treatments in taxation, international trade and other aspects, the four CSEZs quickly stood out from their surrounding areas and from the rest of the country in economic growth, increases in employment, surges in FDI and expansion of exports. In less than four years, almost all of the CSEZs doubled their GDP (Table 19.1). The development of Shenzhen was particularly stunning. By the end of 1983, Shenzhen's GDP reached 1.3 billion yuan-about five times the figure for 1979 — and inward FDI reached HK\$2.98 billion. Industrial output reached 1.66 times the total output during the whole period from 1949 to 1978; and fiscal revenue was 10.9 times that of 1978 (Zhao and Chen 1984:82).

Encouraged by the success of the four CSEZs, the central government decided to further open 14 cities in the coastal area while continuing support for the four experimental CSEZs. ${ }^{2}$ Among 10 new policy initiatives in promoting 
economic reform and development in the coastal areas, establishing the ETDZs has been regarded as the most effective.

Expectations for the newly established ETDZs were initially very high. The central government required the first group of ETDZs to function as 'four windows'; that is, a window of advanced technology, a window of excellent management, a window of new knowledge and a window for the open-door policy. These high expectations reflected the great ambitions of then leaders

Table 19.1 GDP of five SEZs and national total, 1980-2005 (RMB million)

\begin{tabular}{|c|c|c|c|c|c|c|c|}
\hline & Shenzhen & Zhuhai & Shantou & Xiamen & Hainan & National total & $\begin{array}{c}\text { Share } \\
\text { (per cent) }\end{array}$ \\
\hline 1980 & 270 & 261 & 1,079 & 640 & 1,933 & 454,562 & 0.92 \\
\hline 1981 & 496 & 318 & 1,262 & 741 & 2,223 & 488,946 & 1.03 \\
\hline 1982 & 826 & 353 & 1,416 & 867 & 2,886 & 533,045 & 1.19 \\
\hline 1983 & 1,312 & 406 & 1,340 & 944 & 3,112 & 598,555 & 1.19 \\
\hline 1984 & 2,342 & 678 & 1,740 & 1,229 & 3,718 & 724,375 & 1.34 \\
\hline 1985 & 3,902 & 981 & 2,404 & 1,836 & 4,326 & 904,074 & 1.49 \\
\hline 1986 & 4,164 & 1,110 & 2,836 & 2,119 & 4,803 & $1,027,438$ & 1.46 \\
\hline 1987 & 5,590 & 1,590 & 3,865 & 2,549 & 5,760 & $1,205,062$ & 1.61 \\
\hline 1988 & 8,698 & 2,507 & 5,714 & 3,598 & 7,713 & $1,503,682$ & 1.88 \\
\hline 1989 & 11,566 & 3,081 & 6,547 & 4,792 & 9,140 & $1,700,092$ & 2.07 \\
\hline 1990 & 17,167 & 4,143 & 7,245 & 5,709 & 10,249 & $1,871,832$ & 2.38 \\
\hline 1991 & 23,666 & 6,237 & 8,958 & 7,200 & 12,051 & $2,182,620$ & 2.66 \\
\hline 1992 & 31,732 & 10,320 & 10,910 & 9,767 & 18,171 & $2,693,728$ & 3.00 \\
\hline 1993 & 44,929 & 13,400 & 14,862 & 13,232 & 25,810 & $3,526,002$ & 3.18 \\
\hline 1994 & 61,519 & 15,720 & 19,719 & 18,704 & 33,090 & $4,810,846$ & 3.09 \\
\hline 1995 & 79,570 & 18,506 & 26,203 & 25,055 & 36,417 & $5,981,053$ & 3.11 \\
\hline 1996 & 95,004 & 20,732 & 31,366 & 30,635 & 38,950 & $7,014,249$ & 3.09 \\
\hline 1997 & 113,001 & 23,520 & 37,352 & 31,780 & 40,990 & $7,765,313$ & 3.18 \\
\hline 1998 & 128,902 & 26,350 & 42,318 & 41,806 & 43,890 & $8,302,428$ & 3.41 \\
\hline 1999 & 143,602 & 28,660 & 45,459 & 45,829 & 47,120 & $8,818,895$ & 3.52 \\
\hline 2000 & 166,547 & 33,026 & 47,698 & 50,187 & 51,850 & $9,800,045$ & 3.56 \\
\hline 2001 & 195,465 & 36,833 & 48,438 & 53,192 & 55,220 & $10,806,822$ & 3.60 \\
\hline 2002 & 223,941 & 40,903 & 48,978 & 56,135 & 58,557 & $11,909,569$ & 3.60 \\
\hline 2003 & 289,541 & 47,671 & 51,976 & 62,173 & 65,169 & $13,517,398$ & 3.82 \\
\hline 2004 & 342,280 & 55,167 & 54,768 & 68,375 & 72,016 & $15,958,675$ & 3.71 \\
\hline 2005 & 400,468 & 63,495 & 57,397 & 74,788 & 79,150 & $18,395,610$ & 3.67 \\
\hline
\end{tabular}

Sources: Data of five SEZs before 2000 are from Wang, G., 2004. Research on Sustainable Development of China's Five Special Economic Zones (in Chinese), Jingjiguanli Chubanshe, Beijing. After 2000, the data are from the local statistical yearbooks in each year; national data are from National Bureau of Statistics, 2006. China Statistical Yearbook, China Statistical Press, Beijing. 
of the reforms to narrow the gaps in technology and economic development between China and the newly industrialised states in East Asia. Particularly, they expected ETDZs to play a key role in introducing high technologies, which was the goal they thought the four CSEZs had failed to achieve.

Expectations, however, appeared unrealistic. The new ETDZs were not able to achieve these requirements due to the rigid administrative system of the local governments, lack of knowledge of internal business practices, poor infrastructure and other factors. In 1989, the central government modified the guiding principle from four windows to 'three foci': focusing on industrial development, utilisation of FDI and exports. The key change of the principles was to relax the requirement for introduction of high and new technologies and attracting more foreign investment.

The central government granted the ETDZs most of the preferential polices and administrative autonomy that the four CSEZs had enjoyed (State Council of the PRC 1984). Those special policies included preferential tax rates on foreigninvested firms located in ETDZs, a high degree of administrative autonomy from the local government and a more flexible management system for foreign trade, land development and banking services.

Preferential tax treatment for foreign-invested enterprises located in ETDZs

The income tax rate for foreign-invested enterprises located in ETDZs was 15 per cent, while it was 24 per cent in the provinces of Guangdong and Fujian, and 30 per cent in the rest of the country. For the foreign-invested enterprises with terms of operation of more than 10 years, starting from the first year of profit making, their income tax for the first two years would be exempted and that for the next three years would be only 7.5 per cent. If the foreign partner of a foreign-invested enterprise reinvested its profit directly into a business in the ETDZ with a term of operation of more than five years, it could apply for a refund of 40 per cent of the income tax paid. If the foreign investor used its profit to launch or expand an export-oriented or technologically advanced enterprise with a term of operation of more than five years, its income tax paid would be fully refunded.

Higher degree of administrative autonomy for the ETDZs

The ETDZs were granted power to approve foreign investment, manage international trade and make local regulations. Originally, any foreign investment in China had to be approved by the central government. Under that 
system, the process of approval was not transparent and the waiting period was very long. After the decentralisation of economic management in the early 1980s, provincial governments were granted power to approve foreign-invested projects of less than US $\$ 5$ million. The ETDZs, however, were granted much higher administrative autonomy than most provinces. For example, ETDZs in Shanghai and Tianjin were granted power to approve foreign-invested projects up to US $\$ 30$ million. The governments of provinces and cities that hosted ETDZs also gave some administrative powers to the ETDZs in order to accelerate the procedure of approving foreign-invested firms.

\section{Other preferential policies}

Such policies include lower interest rates for banking loans, no import duty for investment goods, office equipment and other products used within the ETDZs. Before China unified exchange rates in 1994, the ETDZs were also granted a certain quota of foreign exchange at the official exchange rate, which allowed them to import some consumer goods to make profits to raise capital for construction of infrastructure. Before 1996, the central government also rebated all the tax revenue collected from the firms located in the ETDZs.

These policy incentives have stimulated provincial and local governments' enthusiasm for setting up ETDZs in their areas. In addition to those preferential policies given by the central government, many provincial and local governments promised financial and other support for the ETDZs. This includes selling land for development at lower than market prices, offering full rebates of local tax and providing special treatment in services including electricity and water supply and telecommunications.

The first ETDZ, Dalian Economic and Technological Development Zone (Dalian ETDZ), was approved by the central government in August 1984. Since then, thousands of ETDZs have been established across the country. The development of the ETDZs in China can be divided into three stages: 1984 to 1988, 1992 to 1996, and 2000 to 2004.

The period from 1984 to 1988 was the infant stage of the ETDZs' development. Only 14 ETDZs were approved by the State Council during this period and all were concentrated in nine coastal provinces (see Table 19.2).

Most of the first group of ETDZs was built in remote areas far from the main cities due to concerns about 'the impacts of capitalism'. This made the investment environment extremely harsh. Poor infrastructure, lack of investment capital, restrictions on original management systems and a shortfall of talent were the main constraints on development at this stage. 


\section{Table 19.2 Establishment of economic and technological development zones (ETDZs), 1984-2002}

\begin{tabular}{|c|c|c|c|}
\hline Period & Number & Approved ETDZs & Province $^{a}$ \\
\hline $1984-88$ & 14 & $\begin{array}{l}\text { Dalian, Qinhuangdao, Tianjin, } \\
\text { Yantai, Qingdao, Lianyungang, } \\
\text { Nantong, Minhang, Hongqiao, } \\
\text { Caohejing, Ningbo, Fuzhou, } \\
\text { Guangzhou, Zhanjiang }\end{array}$ & $\begin{array}{l}\text { Shanghai, Tianjin, Liaoning, Hebei, } \\
\text { Shandong, Jiangsu, Zhejiang, Fujian, } \\
\text { Guangdong (9 provinces) }\end{array}$ \\
\hline 1992-93 & 18 & $\begin{array}{l}\text { Yingkou, Changchun, } \\
\text { Shenyang, Harbin, Weihai, } \\
\text { Kunshan, Hangzhou, Xiaoshan, } \\
\text { Wenzhou, Hongqiao, Dongshan, } \\
\text { Guangzhou Nansha, } \\
\text { Huizhou Dayawan, Wuhu, } \\
\text { Wuhan, Chongqing, } \\
\text { Beijing, Urumchi }\end{array}$ & $\begin{array}{l}\text { Beijing, Chongqing, Heilongjiang, } \\
\text { Jilin, Hubei, Xinjiang, Hainan } \\
\text { (7 provinces) }\end{array}$ \\
\hline $2000-02$ & 17 & $\begin{array}{l}\text { Hefei, Zhengzhou, Xi'an, } \\
\text { Changsha, Chengdu, Kunming, } \\
\text { Guinyang, Nanchang, Shihezi, } \\
\text { Xining, Huhhot, Taiyuan, } \\
\text { Nanning, Yinchuan, Lanzhou, } \\
\text { Lasa }\end{array}$ & $\begin{array}{l}\text { Inner-Mongolia, Shanxi, Anhui, } \\
\text { Jiangxi, Henan, Hunan, Sichuan, } \\
\text { Yunnan, Guizhou, Shaanxi, Qinghai, } \\
\text { Ningxia, Gansu, Tibet (14 provinces) }\end{array}$ \\
\hline
\end{tabular}

a Provinces that were allowed to build ETDZs for the first time.

Source: Department of Foreign Investment Management in Ministry of Commerce, 2007.

National Level Economic and Technological Development Zones Main Economic Indices, Beijing.

The efforts of the newly approved ETDZs in this period focused mainly on infrastructure construction, making connections with potential overseas investors and reforming management systems. These efforts laid a sound foundation for future development, but the inflow of foreign investment and other economic development were very limited in this period. The ETDZs experienced severe stagnation, particularly in the period from 1989 to 1991, because of political retrogression and resulting adverse changes in the international environment. By the end of 1991, the main economic indicators of the first group of ETDZs were not impressive at all (Table 19.3).

The second stage of ETDZs' development-regarded as the 'golden period'was from 1992 to 1996. A large number of new ETDZs and other forms of EDZs were approved, including 18 ETDZs approved by the State Council (Table 19.2). During this period, the first group of 14 ETDZs were really taking off. Table 19.3 
Figure 19.1 Distribution of state-level ETDZs in China

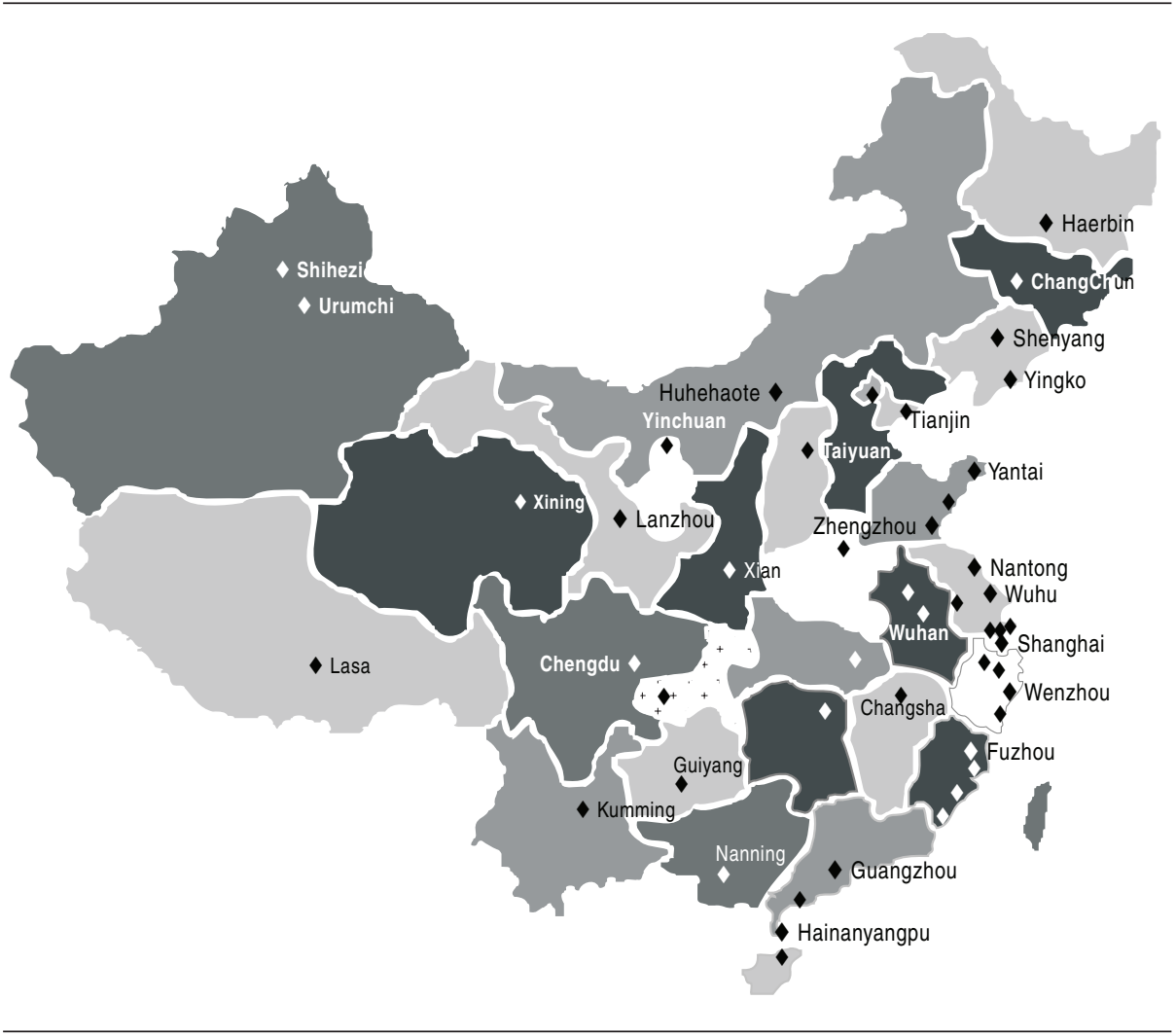

Table 19.3 Economic indicators of the first group of 14 ETDZs, 1991, 1996 and 2005

\begin{tabular}{ccccccc}
\hline & GDP & $\begin{array}{c}\text { Industrial } \\
\text { output } \\
\text { (RMB million) }\end{array}$ & Import & Export & $\begin{array}{c}\text { Realised } \\
\text { FDI }\end{array}$ & $\begin{array}{c}\text { Tax } \\
\text { revenue }\end{array}$ \\
1991 & (RMB million) & (US\$ million) & (US\$ million) & (RMB million) \\
1996 & $7,611.5$ & $14,594.0$ & $1,094.4$ & $1,140.0$ & $1,377.0$ & 790.0 \\
2005 & $356,590.0$ & $188,786.0$ & $6,127.0$ & $6,419.0$ & $3,832.0$ & $10,145.0$ \\
& & $916,384.2$ & $44,231.1$ & $45,308.1$ & $4,662.6$ & $55,134.3$ \\
\hline
\end{tabular}

Source: Department of Foreign Investment Management in Ministry of Commerce, 2007. National Level Economic and Technological Development Zones Main Economic Indices, Beijing. 
shows that the main economic indicators of the first group of ETDZs improved dramatically. In 1996, their GDP was 12.9 times that in 1991. Industrial output increased 12.9 times, imports and exports 5.6 times, foreign investment 2.8 times and tax revenue 12.8 times. Many multinational corporations started to enter the ETDZs, including Motorola, West Pacific Petrochemical, P\&G and Samsung.

The third development period of the ETDZs was from 2000 to 2002. The ETDZs had spread quickly to all areas of the country, but the rapid increase in this period followed a very different pattern compared with the previous two periods in terms of geographic distribution. Newly established ETDZs were located mainly in the central and western areas, in contrast with the previous geographical concentration in coastal areas. Table 19.2 shows that all of the newly established national-level ETDZs were located in the western and central areas (Figure 19.1). As a result, by the end of this period, every province, municipality and autonomous region had at least one national-level ETDZ. This new trend was in accord with the government's regional policy of developing the western area.

By the end of 2002, the number of various kinds of ETDZs in the whole country had soared to 6,866; and the planning area for various ETDZs reached 38,600 square kilometres. In July 2003, the State Council decided to stop approving new ETDZs and started a nation-wide clean-up and rectification of existing ETDZs. Up to the end of 2006, the number of ETDZs was reduced to 1,568, and the planning area was reduced to 9,949 square kilometres (Zhu 2007). Among the surviving EDZs, 222 were approved directly by the State Council as nationallevel EDZs. They include 49 ETDZs, 53 HTDZs, 15 TFZs, 58 EPZs, 14 BECZs and 33 other zones, such as special tourist zones and special logistical zones.

\section{Impacts of ETDZs on China's economic reform and development}

The purpose of establishing SEZs or ETDZs is to promote economic growth, create employment opportunities, attract FDI and expand international trade. Suffice to say, ETDZs have played a significant role in China's economic reform and economic growth.

\section{A driving force for economic growth}

Many local governments have regarded ETDZs as an effective means of fostering a new point of economic growth within their area. That is part of the reason why the number of ETDZs had proliferated to more than 6,000 by the end of 2002. The major economic indicators of 54 national-level ETDZs (hereafter NETDZs) demonstrate the significant contribution of the zones to 
China's national economic growth. ${ }^{3}$ The economic size of the 54 NETDZs is estimated to account for about 73 per cent of all EDZs and about 86 per cent of all 222 NEDZs. ${ }^{4}$

Continuously higher GDP growth rates in the NETDZs compared with the national total in the past two decades means constant increases of their GDP share in the national total. This trend implies a direct contribution of the ETDZs to the country's economic growth.

Tables 19.4 and 19.5 show that the share of the 54 NETDZs in the national total of GDP reached 4.5 per cent and 4.8 per cent in 2005 and 2006, respectively. Their growth rates were 24.14 per cent and 24 per cent respectively-14.2 and 13.3 percentage points higher than the national level. The contribution of the NETDZs to the net growth of GDP was 9.7 and 9.69 per cent respectively. The GDP produced in the first group of 14 NETDZs accounted for about 43.4 per cent of that of the total NETDZs, and their share in the national total GDP was 1.95 per cent (Table 19.6).

In addition to the contribution from the NETDZs, the five CSEZs have made a significant contribution to national economic growth. Their share in total national GDP increased from less than 1 per cent in 1980 to 3.7 per cent in 2005 (Table 19.7).

People could argue that the higher GDP growth in the NETDZs and the CSEZs might not be due to a creation effect but a diversion effect. Some people question whether the high GDP growth of the NETDZs and the CSEZs has been realised at the expense of a slowing of GDP growth in other areas. I do not have a complete data set to answer this question fully. However, based on the data in Tables 4 and 5, without the contribution from the ETDZs in 2005 and 2006, the national growth rates would still be very high: 8.9 and 9.7 per cent respectively-only about one percentage point lower in each year than they were.

Investigation of the economic structure in the NETDZs also seems to support the creation argument. Tables 4 and 5 show a clear international orientation of the NETDZs' economies. The expanding speed of international trade was much faster than the growth rates of GDP_-a significant sign of market creation rather than resource diversion. The growth rates of exports were about 36 and 31 per cent in 2005 and 2006 respectively. Imports witnessed similar rapid growth. The two tables also show that the shares of the NETDZs' international trade and FDI in the national total were three to four times their share of GDP in the national total. Their contribution rate to total exports and FDI in the country was as high as 17 and 62 per cent respectively in 2006. 


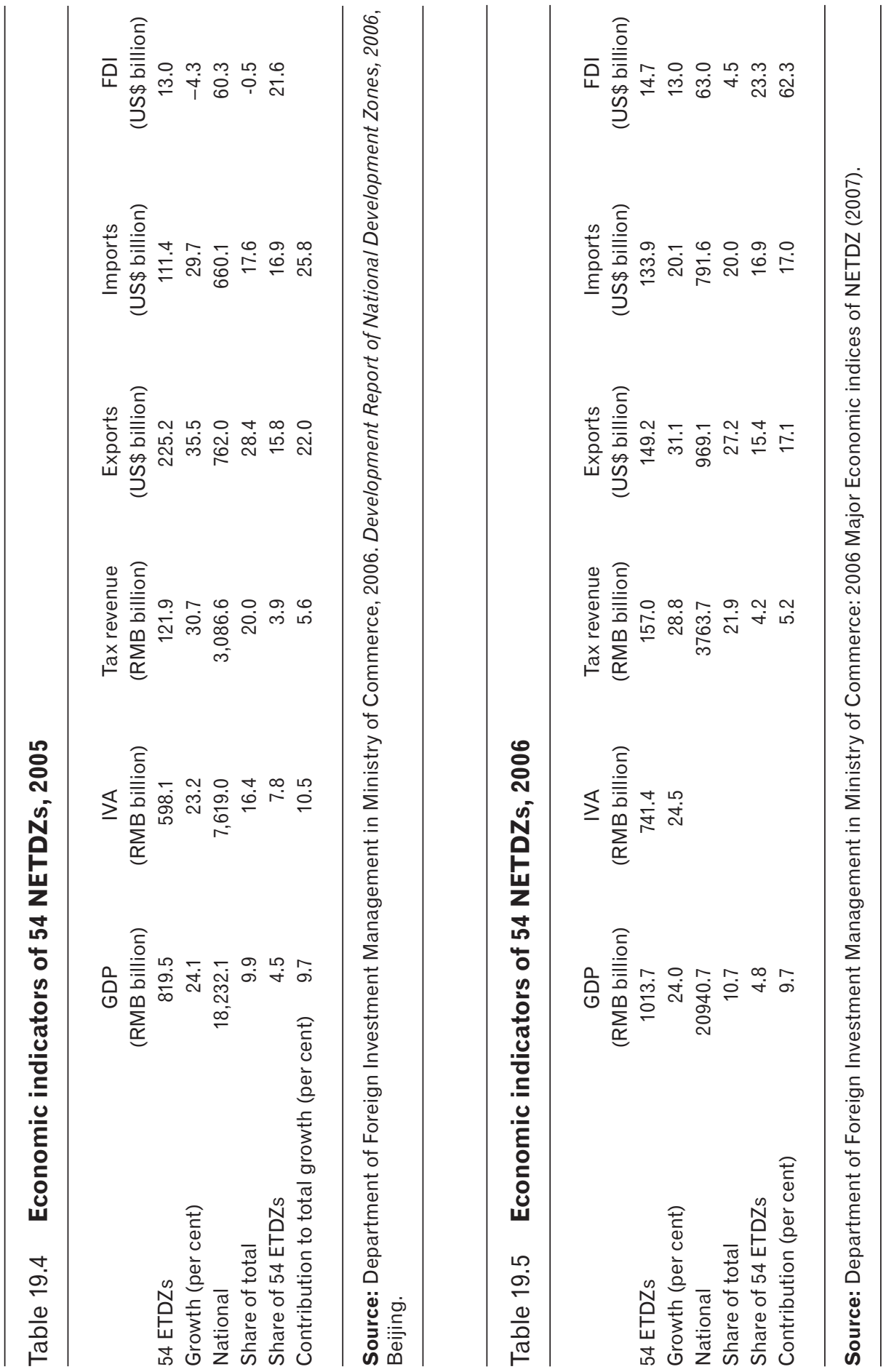




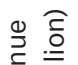

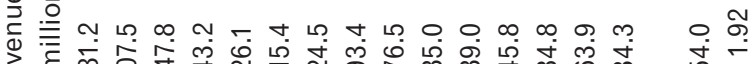

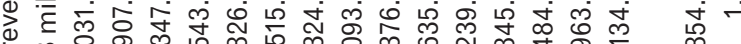

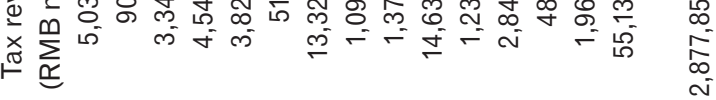

무응

o

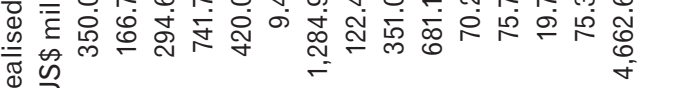

此

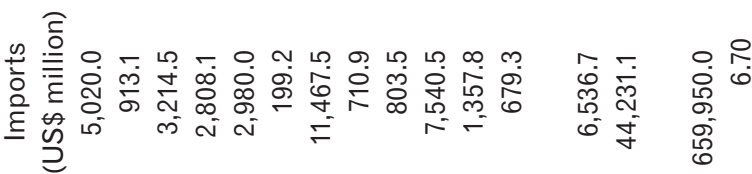

容

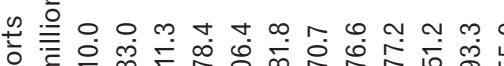

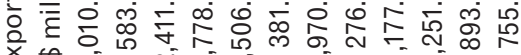

ㅇํㅇ

त N

min $=0$

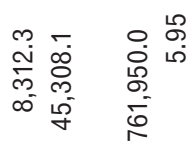

蒙

כ. 은 0 o o d n

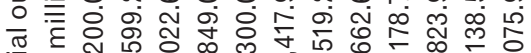

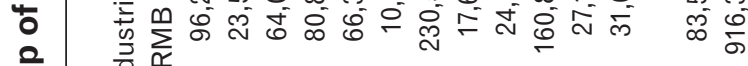

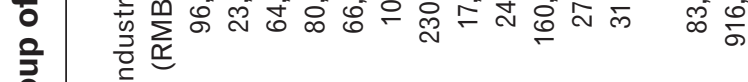

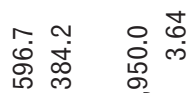

प一

은 $\stackrel{ }{\underline{0}}$

กิำ

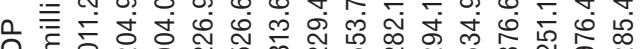

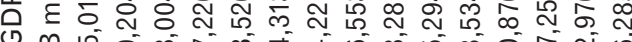

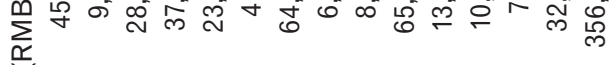

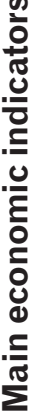

ต்

ำ

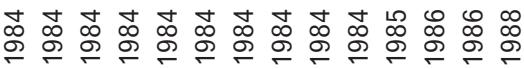

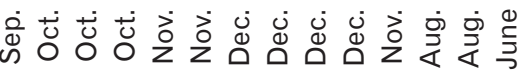

产

$\frac{5}{5}$

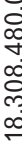

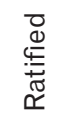

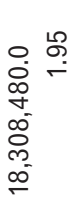




\section{A positive factor for improving economic quality}

The NETDZs have not only made great contributions to national economic growth, they have played a positive role in improving the quality of the national economy.

There is no absolute measurement for economic quality. If we use the absolute level of technology contained in production or products as a measurement, compared with industrialised economies, most developing economies would be regarded as low-quality economies. If, however, we take a dynamic perspective and regard the economic quality as a constantly changing variable, it should not be difficult to measure a process of improvement in economic quality.

A simple way to measure the economic quality of a country is to look at the changes in its international competitiveness, especially its export share in the world total, except for natural resource-intensive commodities. Based on this measurement, the share of China's exports in the world total was less than 0.9 per cent in 1980 (World Bank 2005); it increased to 7.3 per cent by 2005 (WTO 2005). BECZs have played a strong role in strengthening China's international competitiveness and expanding China's share in total world trade.

We can also look at changes in the economic structure, especially changes in the share of high-tech industries in the whole economy. China's State Commission of Science and Technology promulgated the High-Tech Products Catalogue in 1991, based on international standards, particularly the definition made by the Organisation for Economic Co-operation and Development (OECD). The catalogue has since been updated every few years (State Commission of Science and Technology 1991). The current catalogue covers mainly information technology, software, aerospace, optical, mechanical and electrical integration, bio-medicine and medical equipment, new materials, new energy and highly efficient energy savings, environmental protection, oceans and space, nuclear application technology and modern agriculture.

According to this definition of high-tech products or high-tech industries, the NETDZs have played an active role in improving China's economic quality by increasing the number of high-tech enterprises in China and expanding the shares of high-tech products in production and exports.

By the end of 2005, the number of high-tech enterprises in the NETDZs reached 3,205-an increase of 6.7 per cent on a year-on-year basis. In the meantime, employees in high-tech enterprises totalled 830,800 , accounting for 20 per cent of all employees in the 54 NETDZs.

In 2005, the high-tech enterprises realised industrial output of 1,086.1 billion yuan, an increase of 31.9 per cent from the previous year, accounting for 46.5 
per cent of the total. Sales revenue of high-tech products reached 1,088.8 billion yuan, an increase of 24.5 per cent, accounting for 47.1 per cent of the total sales revenue of industrial products in the zones. Exports of high-tech products in the zones reached US $\$ 77.4$ billion, an increase of 49.5 per cent, accounting for 68 per cent of total exports in the zones (Table 19.8).

The surge of high-tech enterprises and their production, sales and exports of high-tech products in the NETDZs has been driven by the investment of many large multinationals. Among them, the top 500 businesses increased their investment in the ETDZs rapidly in recent years. In 2003, the top 500 had invested in 915 enterprises. This number increased to 1,308 by the end of 2005, an increase of 393 in two years-more than 20 per cent of the average annual growth rate.

\section{Table 19.7 Average annual changes in GDP share of five CSEZs in the national total, 1980-2005}

\begin{tabular}{lcc}
\hline Period & $\begin{array}{c}\text { Share } \\
\text { (per cent) }\end{array}$ & $\begin{array}{c}\text { Anuual increase in share } \\
\text { (percentage point) }\end{array}$ \\
1980 & 0.9 & 0.1 \\
$1981-85$ & 1.5 & 0.2 \\
$1986-90$ & 2.4 & 0.2 \\
$1991-95$ & 3.1 & 0.1 \\
$1996-2000$ & 3.6 & 0.02 \\
$2001-05$ & 3.7 & \\
\hline
\end{tabular}

Source: Author's calculations based on Table 19.1.

\section{Table 19.8 High-tech enterprises in 54 NETDZs, 2005}

\begin{tabular}{lccc}
\hline & High-tech & $\begin{array}{c}\text { Change } \\
\text { (per cent) }\end{array}$ & $\begin{array}{c}\text { Share } \\
\text { (per cent) }\end{array}$ \\
Enterprises & $3,205.0$ & 6.6 &.. \\
Employment ('000 persons) & 830.8 &.. & 20.0 \\
Industrial output (RMB billion) & $1,086.1$ & 31.9 & 46.5 \\
Industrial sales (RMB billion) & $1,088.8$ & 24.5 & 47.1 \\
Exports (US $\$$ billion) & 77.4 & 49.5 & 68.0 \\
\hline
\end{tabular}

Source: Calculations based on Department of Foreign Investment Management in Ministry of Commerce, 2006. Development Report of National Development Zones, 2006, Beijing. 
Since the share of NETDZs in the national economy has become significant and is still growing, improvements in industrial quality in the NETDZs have been an important part of improvements in the national economy. In addition, through the industrial linkages with enterprises located outside the NETDZs, high-tech enterprises in the NETDZs help with the general improvement of quality in the national economy through a spillover of technologies, international standard management and marketing practices, as well as other business activities.

\section{An effective catalyst for national economic reform}

Developing NETDZs has been a major component of China's open-door policy. As is well known, such policies have been aimed not only at the development of China's external sectors-including foreign trade and investment-they have functioned very well as a pioneering experiment for many of China's domestic reform policies.

Many new policies were first experimented with in the CSEZs or the NETDZs before being adopted as national policies and implemented elsewhere, such as simplifying government approval procedures for foreign investment, decentralising the control of trade rights from the central to local governments, liberalising the labour market and personnel management systems, establishing socially pooled pension systems and other insurance schemes. These policies were all implemented first in the CSEZs and the NETDZs.

For example, in the early 1980s, to gain government approval to open a joint venture or a foreign-owned enterprise in China, potential foreign investors had to visit more than 50 government agents, from the local to the provincial government, and finally to the central government in Beijing. This procedure took more than a year-in many cases even longer. It was time-consuming and financially costly, making most foreign-invested projects, especially small business projects, impossible.

When the central government approved the first group of NETDZs in the coastal areas, it decided to decentralise the approval power to the governments of the provinces where the NETDZs were located. Most of the provincial governments further passed on the power to the NETDZs in order to improve foreign investment management efficiency. The decentralisation enabled the NETDZs to cut red tape and streamline the approval process. These policy measures became a key attraction for overseas businesspeople to invest in the NETDZs. They also facilitated a surge in foreign investment in the 1990s.

Using a special zone to experiment with some reform measures was not always necessary (Madani 1999). The obstacles to implementing many reform 
policies at the national level in transitional countries are mainly to do with political unwillingness, not economic logic.

In the case of China, the society as whole might have benefitted more if some reform policies could have been implemented directly at the national levelsuch as cutting red tape in government business administration, reforming the labour market and encouraging private business. Reformist leaders did not want to restrict such policy experiments to the CSEZs and the ETDZs. Instead, the experiment usually came about as a result of political compromise.

Government agencies at the central and local levels did not want to give up their powers and risk losing opportunities for rent seeking. They found political allies among conservative leaders. At the same time, although the reformist leaders were willing to adopt much more flexible economic management systems, they could not afford to lose political support from the bureaucratic system and therefore risk their political control of the country. So they chose the second best: that is, to let the bureaucrats continue to exert administrative power over national economic activities for a certain period. At the same time, they could experiment with new policies in limited areas.

This became a process of creation of demand for the reform policies. The basic political logic was that the success of the new policies experimented with in the CSEZs and the NETDZs caused fierce competition among regions to attract foreign investment and to develop local economies. Therefore, it created new demand in other areas for the popularisation of such policies; it also changed public views and gained political support.

The CSEZs and the NETDZs gained huge advantages in economic competition because of the implementation of many bold reform policies, while most other areas in the country were still being restrained by the old system. Their success reduced political obstacles to implement those policies nation-wide.

\section{Limitation of the ETDZs and new challenges in the WTO era}

China has experienced profound changes in the past three decades. These changes occurred not only in its macroeconomic management system, economic strength and structure, but in its economic and political relations with the rest of the world. In a changed environment, the CSEZs and the ETDZs have started to show some inherent limitations.

Although their role in promoting national economic growth will continue for a certain period, the growth rate of the marginal contribution to the national economy will slow. This trend has already appeared in the CSEZs' performances in recent years. The GDP share of the five CSEZs in the national total increased 
rapidly from the early 1980s to the early 1990s, but the growth rate of the GDP share started to slow from the middle 1990s (Figure 19.2).

One explanation for this trend is that with improved investment environments nation-wide, the competition to attract investment has become increasingly fierce. Particularly since many economic reform policies have already spread to the whole country, the original institutional advantages the CSEZs and NETDZs enjoyed will disappear.

It seems unlikely that the CSEZs and the ETDZs will continue to benefit from future reform experiments. China has maximised the benefits it could have received from a piecemeal reform strategy. The Chinese government has tried hard to identify and solve problems with easy solutions and the least amount of risk. Now it has to face uphill battles. Future reforms will focus on the financial sector, social insurance, income disparities and other important economic and social issues. They will have to be dealt with in a more systematic method and experiments in limited areas will simply not work.

In addition to the above-mentioned factors, rapid increases in land and labour costs in coastal areas will limit further growth of ETDZs. All the CSEZs and most of the ETDZs are located in coastal areas, where population intensity is high. Therefore, land supply is limited. Rapid increases in land prices will directly increase investment costs. At the same time, land prices will also push

Figure 19.2 GDP share of five SEZs in the national total, 1980-2005 (per cent)

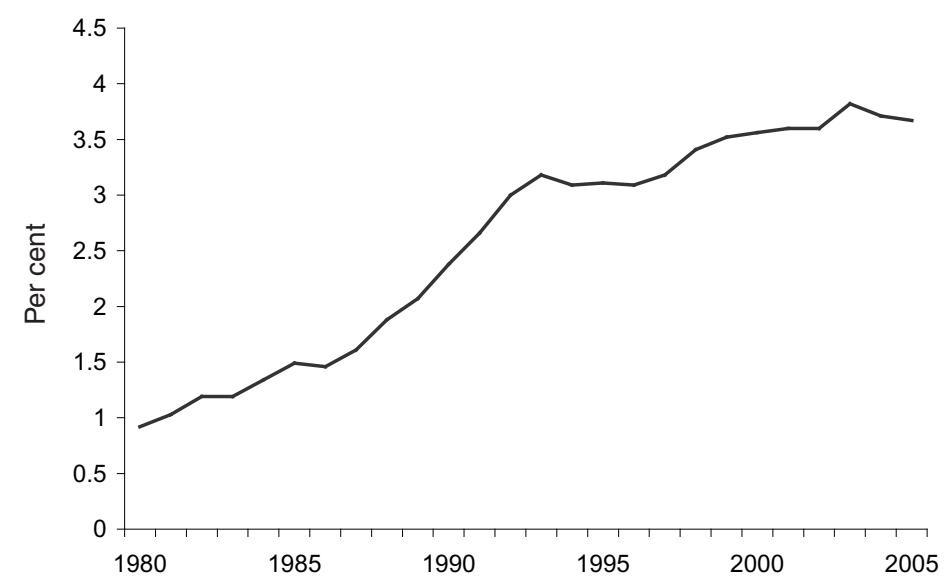

Source: Author's calculations based on Table 19.1. 
housing costs up further, which will flow on to living and labour costs.

China has been a member of the WTO since December 2001. Its WTO obligations have some important direct policy implications for the CSEZs and the ETDZs. With all the agreements China signed when it was admitted into the WTO, two are particularly relevant to SEZs: the Agreement on Subsidies and Countervailing Measures (SCM), and the Trade Related Investment Measures (TRIMS) Agreement.

According to the SCM agreement, if three elements are satisfied at the same time, any investment incentives provided by the government should be regarded as subsidies. The three elements are a financial contribution by a government or any public bodies; a benefit is conferred; a subsidy specific to an enterprise or industry or group of enterprises or industries.

The SCM agreement also specifies a definition of financial contributions. It states that any of the following actions equate to a financial contribution

- a direct transfer of funds such as grants, loans and equity infusion, and potential direct transfers of funds or liabilities such as loan guarantees

- if revenue otherwise due to government is forgone or not collected, that is, fiscal incentives such as tax credits

- the government provides goods or services other than general infrastructure, or purchases goods

- the government carries out one of the above functions through a private body that would normally be vested in the government.

All subsidies under the SCM agreement are categorised into two types: prohibited subsidies and actionable subsidies. Export subsidy is one of two types of prohibited subsidies.

According to the definitions in the SCM agreement, many of the existing preferential treatments for foreign-invested enterprises in the ETDZs should be deemed as subsidies, and are thus inconsistent with China's WTO obligations. For example, the CSEZs and the ETDZs provide several forms of incentives, such as lower enterprise income tax rates, exemption from income tax for a certain period, further reduction of income tax for export-oriented enterprises, provision of basic services at a price lower than market prices, and so on.

China's alleged export subsidy has always been one of the main trade disputes between China and the United States, the European Union and its other main trade partners. Some of the disputed products are produced in the CSEZs and the ETDZs.

Being aware of the inconsistency between its preferential polices granted to various forms of SEZs and its commitment to its WTO obligations, the Chinese government has been gradually changing some policies. Passing the new 
enterprise income tax law is a significant step towards eliminating the de facto subsidies to foreign-invested firms located in CSEZs and ETDZs.

Although facing some limitations and challenges, the ETDZs will have to change their role in the national economy in future. Suffice to say, after more than two decades of development, many ETDZs—in particular, NETDZs—have built up a relatively modern infrastructure and a sound industrial foundation. Some of them have formed an industrial cluster with the characteristics of 'geographic concentrations of interconnected companies, specialized suppliers, service providers, and associated institutions in a particular field' (Porter 1998). As industrial centres in the regions, they will be able to receive benefits from the economy of scale and become self-sustaining and self-enhancing, according to Krugman's theory of geography and trade (1991).

\section{Conclusion}

Since 1979, in order to promote economic growth and develop international economic relations, the Chinese government has set up various forms of SEZs. It started with four SEZs in southern China in 1979, then 14 economic and technological development zones in the coastal areas in 1984. In the 1990s and early 2000s, the economic and technological zones and other forms of SEZs flourished across the country. Now there are 1,568 economic and technological development zones with a total planning area of 9,949 square kilometres.

With special preferential treatments in taxation and other financial incentives, as well as a higher degree of administrative autonomy, the various forms of SEZs_-in particular, 54 national-level ETDZs_have witnessed rapid increases in FDI, international trade and industrial production. They have played a significant role in promoting national economic growth, improving overall economic quality and pioneering economic reform.

There appear to be some limitations that will restrain China's SEZs from continuing to grow and expand their share in the national economy with the speed they experienced in the past two decades. This is mainly because the institutional gap between these SEZs and the rest of the country has gradually narrowed and will soon disappear. As a result, they will not continue to benefit from preferential treatment. Realisation of China's WTO obligations will further speed up this process.

After two decades of development, however, some SEZs and ETDZs have established an advantageous status as regional industrial centres. This status will enable them to continue to receive the benefits of the economy of scale and to realise self-enhancement in future development. 


\section{Notes}

1 The central government approved the fifth SEZ, Hainan, in April 1988.

2 The 14 coastal cities are Shanghai, Tianjin, Dalian, Qinhuangdao, Qingdao, Yantai, Lianyungang, Nantong, Ningbo, Wenzhou, Fuzhou, Guangzhou, Zhanjiang and Beihai.

3 In China's official document, 54 ETDZs include 49 ETDZs listed in Table 19.2 and another five EDZs, which enjoy the same preferential policies as the 49 state-level ETDZs: Suzhou Industrial Park, Hainan Yangpu ETDZ, Shanghai Jinqiao Export Processing Zone, Ningbo Daxie ETDZ and Xiamen Haicang Investment Zone (Department of Foreign Investment Management in Ministry of Commerce 2006).

4 A complete data set for all 1,568 EDZs, or even for 222 state-level EDZs, is unavailable. A short time data set for 54 state-level ETDZs is, however, relatively reliable. I have based my analysis of the ETDZs on the data of 54 state-level ETDZs.

\section{References}

Aggarwal, A., 2006. 'Special economic zones: revisiting the policy debate', Economic and Political Weekly, 4 November:4,533-6.

Carttier, C., 2001. 'Zone fever, the arable land debate and real estate speculation: China's evolving land use regime and its geographical contradictions', Journal of Contemporary China, 10(28):445-69.

Crittle, J. and Akinci, G., 2004. Do the benefits of special economic zones outweigh their costs?, Archived Discussion, July, World Bank, Washington, DC. Available from http://rru.worldbank.org/Discussions/Topics/Topic40. aspx (accessed 25 April 2007).

Department of Foreign Investment Management in Ministry of Commerce, 2006. Development Report of National Development Zones, 2006, Beijing.

——, 2007. National Level Economic and Technological Development Zones Main Economic Indices, Beijing.

Gopalakrishnan, S., 2007. 'Negative aspects of special economic zones in China', Economic and Political Weekly, 28 April:1,492-4.

Jayanthakumaran, K., 2003. 'Benefit-cost appraisals of export processing zones: a survey of the literature', Development Policy Review, 21(1):51-65. Krugman, P., 1991. Geography and Trade, The MIT Press, Cambridge, MA. Madani, D., 1999. A review of the role and impact of export processing zones, World Bank Policy Research Working Paper, No. 2238, World Bank, Washington, DC.

National Bureau of Statistics, 2006. China Statistical Yearbook, China Statistical Press, Beijing.

Porter, M.E., 1998. On Competition, Harvard University Business School Press, Cambridge, MA. 
State Commission of Development and Reform, Ministry of Land and Natural Resources, and Ministry of Construction, 2006. Contents of National Development Zone Auditing Notice (in Chinese), Beijing.

State Commission of Science and Technology, 1991. High-Tech Products Catalogue (in Chinese), State Commission of Science and Technology Beijing.

State Council of the PRC, 1984. The Minutes of the Conference of Some Coastal Cities (in Chinese), Beijing.

Wang, G., 2004. Research on Sustainable Development of China's Five Special Economic Zones (in Chinese), Jingjiguanli Chubanshe, Beijing.

Weil, R., 1996. Red Cat, White Cat: China and the contradictions of market socialism, Monthly Review Press, New York.

World Bank, 2005. World Development Indicators, World Bank, Washington, DC.

World Export Processing Zones Association (WEPZA), 2007. WEPZA Table of Zone Countries, Evergreen, CO. Available from http://www.wepza.org (accessed 16 April 2007).

World Trade Organization (WTO), 2005. World Trade in 2005-Overview:Tables 1-5, World Trade Organization, Washington, DC.

Zhao, Y. and Chen, Z., 1984. Economies of the Special Economic Zones in China (in Chinese), Kexue Puju Chubanshe Guangzhou Fenshe, Guangzhou.

Zhu, J., 2007. 'Quanguo Qingli Gelei Kaifaqu Chujian Chengxiao (Initial achievement has been made in putting various development zones in order)', Renmin Ribao, 23 April, Beijing:1. 